\title{
Effect of Date of Sowing and Nutrient Management on Nutrient Uptake and Yield of Foxtail Millet (Setaria italica L.)
}

\author{
P. Mubeena*, A. S. Halepyati and B. M. Chittapur
}

Dept. of Agronomy, College of Agriculture, University of Agricultural Sciences, Raichur (584 104), India

\section{Corresponding Author}

P. Mubeena

e-mail: mubeenap94@gmail.com

\author{
Article History \\ Article ID: AR1891 \\ Received in $07^{\text {th }}$ August, 2018 \\ Received in revised form $20^{\text {th }}$ February, 2019 \\ Accepted in final form $28^{\text {th }}$ February, 2019
}

\begin{abstract}
A field experiment was conducted at College of Agriculture Farm, Raichur on medium black soil during kharif, 2017 to study the effect of date of sowing and nutrient management on nutrient uptake and yield of foxtail millet (Setaria italica L.). The experiment was laid out in split-plot design with three replications. The treatments consisted of four sowing dates (second fortnight of June, first fortnight of July, second fortnight of July and first fortnight of August) and three levels of RDF (75\%, 100\% and $125 \%$ RDF). The results revealed that, early sowing during second fortnight of June recorded significantly higher uptake of nitrogen $\left(112.12 \mathrm{~kg} \mathrm{ha}^{-1}\right)$, phosphorus (10.82 kg ha-1 $)$, potassium $\left(60.66 \mathrm{~kg} \mathrm{ha}^{-1}\right)$, grain yield $\left(2368 \mathrm{~kg} \mathrm{ha}^{-1}\right)$, stover yield $\left(8916 \mathrm{~kg} \mathrm{ha}^{-1}\right)$ net returns ( $\left.₹ 24978 \mathrm{ha}^{-1}\right)$ and benefit cost ratio (2.46). However, it was found to be on par with first fortnight of July. A higher nutrient uptake, yield and economics were recorded by the application of $100 \%$ RDF (nitrogen, phosphorus, potassium, grain yield, stover yield, net return, benefit cost ratio; $99.74 \mathrm{~kg} \mathrm{ha}^{-1}, 9.19 \mathrm{~kg} \mathrm{ha}^{-1}, 44.86 \mathrm{~kg} \mathrm{ha}{ }^{-1}, 2140 \mathrm{~kg}$ $\mathrm{ha}^{-1} 7176 \mathrm{~kg} \mathrm{ha}^{-1}$, ₹ $19394 \mathrm{ha}^{-1}$ and 2.13, respectively) and it was in turn on par with 125\% RDF. But, interaction effect of date of sowing and nutrient management was found to be non significant with respect to nutrient uptake and yield. Sowing during second fortnight of June in combination with application of $100 \%$ RDF noted significantly higher grain yield $\left(2424 \mathrm{~kg} \mathrm{ha}^{-1}\right)$, stover yield $(9350 \mathrm{~kg}$ ha-1) and benefit cost ratio (2.51).
\end{abstract}

Keywords: Nutrient uptake, grain yield, stover yield, foxtail millet

\section{Introduction}

Foxtail millet (Setaria italica L.), a member of the family Poaceae, is highly drought resistant crop grown under rainfed condition and produces high quality grains than many other cereals under extreme conditions like unfertile soil, intense heat and prolong drought. In India, the cultivation of foxtail millet is confined to Andhra Pradesh, Karnataka and Tamil Nadu. It is widely grown in Haveri, Dharwad and Belgum districts of Northern Transitional Zone of Karnataka. Proper time of sowing is one of the major non-monetary inputs which if managed properly could boost the productivity in terms of quality and quantity both without increasing the cost of cultivation and affecting the soil and environmental health. Therefore, to keep the pace with estimated requirement there is a need to identify suitable time for sowing to minimize the end result of the changing climatic condition and at the same time to increase the production of foxtail millet. The yield potential of minor millets including foxtail millet has been very low under rainfed area because of practically negligible use of fertilizers, conventional cultivation of low yielding cultivars and lack of good management practices. The common belief is that minor millets may not profitably respond to applied nutrients under rainfed condition. No doubt application of fertilizers becomes essential need for high yielding varieties of minor millets to exploit their maximum potential. So, experiment was conducted to know the effect of date of sowing and nutrient management on the nutrient uptake and yield of foxtail millet (Setaria italica L.).

\section{Materials and Methods}

A field experiment was conducted during the kharif, 2017 at Agricultural College farm, Raichur which comes under North Eastern Dry Zone (Zone 2) of Karnataka. The experiment was laid out in split-plot design with 12 treatments replicated thrice. The treatments consist of four sowing dates (second fortnight of June, first fortnight of July, second fortnight of July and first fortnight of August) and three levels of RDF (75\%, 100\% and $125 \%$ RDF). A pre release variety, $\mathrm{HN}-46$ was selected for study. Half the dose of nitrogen and entire dose of phosphorous and potassium in the form of urea, diammonium phosphate (DAP) and muriate of potash (MOP) respectively were band placed as per the treatments at the time of sowing. Remaining $50 \%$ of nitrogen was applied at 30 DAS. The soil of the experimental site was medium black, moderately alkaline 
with a pH of 8.4 and had a low nitrogen (202.56 kg ha-1) and medium phosphorus and potassium (18.42 and $257.24 \mathrm{~kg}$ $\mathrm{ha}^{-1}$ ) availability in soil. Sowing was done by dibbling on four different dates $\left(D_{1}: 27^{\text {th }}\right.$ June, $D_{2}: 12^{\text {th }}$ July, $D_{3}: 28^{\text {th }}$ July, $D_{4}: 12^{\text {th }}$ August 2017).

\section{Results and Discussion}

\subsection{Effect of date of sowing}

The grain yield of foxtail millet cv. HN- 46 was significantly influenced due to different dates of sowing (Table 1). Sowing during second fortnight of June recorded significantly higher grain yield ha-1 (2368 $\mathrm{kg} \mathrm{ha}^{-1}$ ) and it was on par with first fortnight of July (2271 kg ha-1). Late sowing during first fortnight of August recorded significantly lower grain yield of $1616 \mathrm{~kg} \mathrm{ha}^{-1}$. Significantly higher yield in second fortnight of June is mainly due to the increase in yield attributing characters like ear head length $(22.30 \mathrm{~cm})$, ear head weight $(10.64 \mathrm{~g})$, grain yield plant $^{-1}(10.86 \mathrm{~g})$ and test weight $(5.24$ g). These parameters were on par with sowing during first fortnight of July. The reason could be that early sown crop had prolonged photoperiod as a result of which higher assimilates were translocated towards ear head and produced maximum number of grains in ear head. Similar results were reported by Amanullah et al. (2015) who recorded higher number of grains panicle ${ }^{-1}$, panicle weight and thousand grain weight in early sowing ( $20^{\text {th }}$ June) as compared to late sowing $\left(10^{\text {th }}\right.$ July and $30^{\text {th }}$ July). These results are in compliance with the findings of Gavit et al. (2017). Earlier sown crop had ideal growth condition as a result bold grains were produced when compared to late sown crop. Similar variations were reported by Teare et al. (1993) and he observed that early sowing (10 ${ }^{\text {th }}$ June)

\begin{tabular}{|c|c|c|c|c|c|c|c|}
\hline Treatments & $\begin{array}{c}\text { No. of tillers } \\
\text { plant }^{-1} \text { at } \\
\text { harvest }\end{array}$ & $\begin{array}{c}\text { Ear head } \\
\text { weight } \\
\text { (g) }\end{array}$ & $\begin{array}{l}\text { Grain yield } \\
\text { plant }^{-1}(\mathrm{~g})\end{array}$ & $\begin{array}{c}\text { Test weight } \\
(1000 \\
\text { grains) }\end{array}$ & $\begin{array}{c}\text { Grain yield } \\
\left(\mathrm{kg} \mathrm{ha}^{-1}\right)\end{array}$ & $\begin{array}{c}\text { Stover } \\
\text { yield } \\
\left(\mathrm{kg} \mathrm{ha}^{-1}\right)\end{array}$ & $\begin{array}{l}\text { Harvest } \\
\text { index }\end{array}$ \\
\hline \multicolumn{8}{|l|}{ Date of sowing (D) } \\
\hline$D_{1}:$ Second fortnight of June & 3.89 & 10.64 & 10.86 & 5.24 & 2368 & 8916 & 0.23 \\
\hline $\mathrm{D}_{2}:$ First fortnight of July & 3.80 & 9.55 & 10.40 & 4.92 & 2271 & 8713 & 0.22 \\
\hline$D_{3}:$ Second fortnight of July & 2.39 & 8.19 & 5.72 & 3.56 & 1992 & 5623 & 0.29 \\
\hline$D_{4}:$ First fortnight of August & 1.32 & 6.10 & 3.74 & 3.47 & 1616 & 4346 & 0.32 \\
\hline SEm \pm & 0.03 & 0.21 & 0.24 & 0.08 & 29.98 & 104.33 & 0.01 \\
\hline $\operatorname{CD}(p=0.05)$ & 0.10 & 0.71 & 0.82 & 0.29 & 103.70 & 360.88 & NS \\
\hline \multicolumn{8}{|l|}{ Nutrient management (F) } \\
\hline $\mathrm{F}_{1}: 75 \% \mathrm{RDF}$ & 2.61 & 8.22 & 7.35 & 4.10 & 2002 & 6492 & 0.28 \\
\hline $\mathrm{F}_{2}: 100 \% \mathrm{RDF}$ & 3.06 & 9.09 & 8.33 & 4.44 & 2140 & 7176 & 0.26 \\
\hline $\mathrm{F}_{3}: 125 \% \mathrm{RDF}$ & 2.88 & 8.55 & 7.37 & 4.35 & 2043 & 7031 & 0.25 \\
\hline SEm \pm & 0.09 & 0.28 & 0.38 & 0.12 & 39.15 & 178.46 & 0.02 \\
\hline $\mathrm{CD}(p=0.05)$ & 0.28 & 0.84 & 1.12 & 0.35 & 116.37 & 530.52 & NS \\
\hline \multicolumn{8}{|l|}{ Interaction (D×F) } \\
\hline SEm \pm & 0.12 & 0.52 & 0.65 & 0.22 & 79.37 & 394.10 & 0.03 \\
\hline $\mathrm{CD}(p=0.05)$ & NS & NS & NS & NS & NS & NS & NS \\
\hline
\end{tabular}

significantly improved seed weight as compared to late sowing (20 th July).

The growth and yield of crop plants were determined by the presence of nutrients in the soil in available form for plant uptake (Table 2). Uptake of nutrients is associated with the concentration of ions in the external medium. There was a decrease in the uptake of nutrients with delaying sowing date. Early sowing during second fortnight of June recorded significantly higher nitrogen uptake $\left(112.12 \mathrm{~kg} \mathrm{ha}^{-1}\right)$ at harvest followed by first fortnight of July $\left(101.38 \mathrm{~kg} \mathrm{ha}^{-1}\right)$. A lower uptake was noticed when crop was sown during first fortnight of August (77.15 kg ha-1). Similar trend was noticed in phosphorus and potassium uptake. This result was in agreement with the result of Gavit et al. (2017).

\subsection{Effect of nutrient management}

The grain and stover yield of foxtail millet was significantly influenced due to the application of RDF (Table 1). Application of $100 \%$ RDF recorded significantly higher grain and stover yield ( $2140 \mathrm{~kg} \mathrm{ha}^{-1}$ and $7176 \mathrm{~kg} \mathrm{ha}^{-1}$ ) and it was on par with 125\% RDF (2043 kg ha-1 and $\left.7031 \mathrm{~kg} \mathrm{ha}^{-1}\right)$. The increase in grain and stover yield with increased nitrogen and phosphorus supply could be explained on the basis of high beneficial effects of nitrogen and phosphorus on growth and yield contributing characters like number of tillers, dry matter production per 


\begin{tabular}{|c|c|c|c|c|c|c|c|}
\hline Treatments & $\begin{array}{c}\mathrm{N} \\
\left(\mathrm{kg} \mathrm{ha}^{-1}\right)\end{array}$ & $\begin{array}{c}\mathrm{P} \\
\left(\mathrm{kg} \mathrm{ha}^{-1}\right)\end{array}$ & $\begin{array}{c}\mathrm{K} \\
\left(\mathrm{kg} \mathrm{ha}^{-1}\right)\end{array}$ & $\begin{array}{l}\text { Cost of } \\
\text { Cultivation } \\
\left(₹ \text { ha }^{-1}\right)\end{array}$ & $\begin{array}{l}\text { Gross } \\
\text { returns } \\
\left(₹ \text { ha }^{-1}\right)\end{array}$ & $\begin{array}{l}\text { Net } \\
\text { returns } \\
\left(₹ \text { ha }^{-1}\right)\end{array}$ & $\begin{array}{l}\mathrm{B}: \mathrm{C} \\
\text { ratio }\end{array}$ \\
\hline \multicolumn{8}{|l|}{ Date of sowing (D) } \\
\hline$D_{1}$ : Second fortnight of June & 112.12 & 10.82 & 60.66 & 17065 & 42044 & 24978 & 2.46 \\
\hline $\mathrm{D}_{2}:$ First fortnight of July & 101.38 & 9.22 & 45.85 & 17065 & 40467 & 23401 & 2.37 \\
\hline$D_{3}:$ Second fortnight of July & 91.36 & 8.13 & 34.47 & 17065 & 32350 & 15285 & 1.90 \\
\hline $\mathrm{D}_{4}:$ First fortnight of August & 77.15 & 7.12 & 25.13 & 17065 & 25304 & 8239 & 1.48 \\
\hline SEm \pm & 1.23 & 0.18 & 0.61 & - & 429 & 429 & 0.03 \\
\hline$C D(p=0.05)$ & 4.25 & 0.62 & 2.10 & - & 1484 & 1484 & 0.09 \\
\hline \multicolumn{8}{|l|}{ Nutrient management (F) } \\
\hline $\mathrm{F}_{1}: 75 \% \mathrm{RDF}$ & 89.73 & 8.48 & 37.89 & 16794 & 33570 & 16776 & 2.00 \\
\hline $\mathrm{F}_{2}: 100 \%$ RDF & 99.74 & 9.19 & 44.86 & 17142 & 36536 & 19394 & 2.13 \\
\hline $\mathrm{F}_{3}: 125 \%$ RDF & 97.04 & 8.80 & 41.84 & 17261 & 35017 & 17756 & 2.03 \\
\hline SEm \pm & 2.50 & 0.25 & 0.86 & - & 509 & 509 & 0.03 \\
\hline $\mathrm{CD}(p=0.05)$ & 7.45 & 0.65 & 2.56 & - & 1512 & 1512 & 0.09 \\
\hline \multicolumn{8}{|l|}{ Interaction (D×F) } \\
\hline SEm \pm & 2.92 & 0.11 & 0.88 & - & 1073 & 1073 & 0.06 \\
\hline $\mathrm{CD}(p=0.05)$ & NS & NS & NS & - & NS & NS & NS \\
\hline
\end{tabular}

plant, ear head weight, thousand grain weight and ear head length (NeerajYadav and Pulla Rao, 2014). Application of RDF increased the concentration of nutrient ions in the soil solution and availability of sufficient nutrients might have helped in higher nutrient uptake. Significantly, higher uptake of nitrogen, phosphorus and potassium (99.74, 9.19 and 44.86 $\mathrm{kg} \mathrm{ha}^{-1}$, respectively) was recorded with $100 \%$ RDF when compared with $125 \%$ and $75 \% \operatorname{RDF}(97.04,8.80$ and $41.84 \mathrm{~kg}$ $\mathrm{ha}^{-1} ; 89.73,8.48$ and $37.89 \mathrm{~kg} \mathrm{ha}^{-1}$, respectively). These results are in accordance with the findings of Nigade and More (2013).

The growth and yield of crop plants were determined by the presence of nutrients in the soil in available form for plant uptake (Table 2). Uptake of nutrients is associated with the concentration of ions in the external medium. Application of RDF increased the concentration of nutrient ions in the soil solution and availability of sufficient nutrients might have helped in higher nutrient uptake. Significantly, higher uptake of nitrogen, phosphorus and potassium (99.74, 9.19 and 44.86 $\mathrm{kg} \mathrm{ha}^{-1}$, respectively) were recorded with $100 \%$ RDF when compared with $125 \%$ and $75 \%$ RDF $(97.04,8.80$ and $41.84 \mathrm{~kg}$ $\mathrm{ha}^{-1} ; 89.73,8.48$ and $37.89 \mathrm{~kg} \mathrm{ha}^{-1}$, respectively). These results are in accordance with the findings of Nigade and More (2013).

\subsection{Interaction effects}

Uptake of NPK and yield were not influenced by the interaction effect of date of sowing and nutrient management (Table 2). Similar study in pearl millet was conducted by Dapake et al. (2016) and he concluded that the interaction between sowing time and nutrient management of pearl millet were found to be non-significant in respect of yield attributing parameters, quality parameters and available NPK status.

\subsection{Economics}

There was significant difference in economic analysis of foxtail millet cv. HN-46 due to sowing during different dates (Table 2). Significantly higher gross returns ( $\left.₹ 42,044 \mathrm{ha}^{-1}\right)$, net returns (₹ 24,978 ha $^{-1}$ ) and benefit cost ratio (2.46) were recorded by sowing during second fortnight of June $\left(D_{1}\right)$. However, first fortnight of August $\left(D_{4}\right)$ recorded significantly lower gross return ( $₹ 25,304$ ha $\left.^{-1}\right)$, net return ( $₹ 8,239 \mathrm{ha}^{-1}$ ) and benefit cost ratio (1.48). The increased gross returns, net returns and benefit cost ratio were mainly due to increased grain and straw yield due to sowing during second fortnight of June $\left(D_{1}\right)$ over rest of the sowing dates. Similar results were also reported by Dapake et al. (2016).

Application of $100 \%$ RDF recorded significantly higher gross returns ( $₹ 36,536 \mathrm{ha}^{-1}$ ), net returns ( $₹ 19,394 \mathrm{ha}^{-1}$ ) and benefit cost ratio (2.13) when compared to the application of $125 \%$ RDF (₹ $35,017 \mathrm{ha}^{-1}$, ₹ $17756 \mathrm{ha}^{-1}$ and 2.03 , respectively) and $75 \%$ RDF (₹ 33,570 ha- ${ }^{-1}$, ₹ $16,776 \mathrm{ha}^{-1}$ and 2.0, respectively). The higher gross and net returns were mainly due to higher economic yield associated with optimum levels of fertilizer applied treatment. These results are in close conformity with reports of Patel et al. (2013).

Interaction effect of date of sowing and nutrient management was found to be non significant with respect to gross returns, 
net returns and benefit cost ratio. This result was in orthodoxy with the result of Dapake et al. (2016).

\section{Conclusion}

Early sowing during second fortnight of June along with application of $100 \%$ RDF recorded significantly higher uptake of NPK, grain yield, stover yield, net returns and benefit cost ratio. However, it was found to be on par with sowing during first fortnight of July and application of $125 \%$ RDF. Interaction effect of date of sowing and nutrient management was found to be non significant with respect to nutrient uptake, yield and economics.

\section{Acknowledgement}

The author provided by financial assistance from Indian Council of Agricultural Research (ICAR) as non-JRF scholarship.

\section{References}

Amanullah, J., Khan, I., Amanullah, S.A., Sohail, A., 2015. Sowing dates and sowing methods influence on growth, yield and yield components of pearl millet under rainfed conditions. Journal of Environment and Earth Science 5(1), 2224-3216.
Dapake, P.P., Chaudhari, P.M., Ghodke, S.K., Patil, M.R., 2016. Effect of sowing time and nutrient management on growth, yield and quality of pearl millet cv. Dhanshakti under rainfed condition. Contemporary Research in India 7(3), 2137-2231.

Gavit, H.D., Rajemahadik, V.A., Bahure, G.K., Jadhav, M.S., Thorat, T.N., Kasture, M.C., 2017. Effect of establishment techniques and sowing time on yield and yield attributes of proso millet (Panicum miliaceum L.). International Journal of Current Microbiology and Applied Sciences 6(5), 1523-1528.

Nigade, R.D., More, S.D., 2013. Performance of finger millet varieties to different levels of fertilizer on yield and soil properties in sub-mountane zone of Maharashtra. International Journal of Agriculture Sciences 9(1), 256-259

Patel, N.I., Patel, J.J., Chatra, R., Sutaliya, J.M., 2013. Effect of NPK fertilizers applied to pearl millet on the basis of soil test values. Green farming 4(4), 433-437.

Teare, I.D., Wright, D.L., Pudelko, J.A., 1993, Physiological development of HGM-100 to planting date and available water. North Florida Research and Education Centre,Quincy, FL32351. 